\title{
A Study on the Reform of English Linguistics Teaching Based on Task-based Teaching Mode
}

\author{
Ziying Yang \\ Chengdu Neusoft University,Chengdu 611844,China
}

Keywords: Teaching method reform, Teaching interaction, Task role, Independent learning.

\begin{abstract}
The task-based teaching, which rose in the 1980s, is an important thought in the teaching method reform. In view of the current teaching of English linguistics, the inspiring characteristics of task-based teaching are in line with the specific requirements of curriculum teaching. In the thesis the problems existing in the teaching process of English linguistics in the past will be systematically analyzed, combined with the teaching objectives of linguistics courses so as to set the direction for teaching reform. Classes will be used to explore the specific practice methods of the task-based teaching mode, as the main means of teaching reform.

Preface: English linguistics is a branch of English, and students can grasp the English language system more systematically through learning phonetics, morphology and semantics in linguistics, and lay a solid foundation for continuing to learn English in the future. To learn linguistics, students need to grasp specific learning methods besides enough enthusiasm and interest. Traditional teaching often focuses on the theoretical content of linguistics, but ignores the students' learning situation and learning attitudes, which is an important reform object of English linguistics teaching.
\end{abstract}

\section{The Problems in English Linguistics Teaching}

\section{The teaching content cannot achieve the teaching objectives}

English linguistics is designed to enable students to understand the language system of English more clearly, so as to help them to combine the learning methods and learning comprehension so as to better grasp the language content and usage. However, in the current teaching of English linguistics, most students and teachers lack a clear concept of linguistics in cognition, and even some students cannot understand the meaning of linguistics and the content of learning after learning for some time. The fundamental reason is that the teaching content is too empty, and cannot achieve the linguistic teaching objectives, so the students cannot fundamentally recognize the linguistic learning purposes and get rich and valuable gains from learning linguistics; meanwhile, teachers also have unclear understanding of teaching objectives of linguistics, which makes teaching design and teaching content lack foundation, and become "teaching for teaching", a castle in the air ${ }^{[1]}$.

\section{Theoretical knowledge infusion}

After decades of development, the traditional teaching methods have been deeply rooted. In the teaching environment in recent years, although there are new teaching ideas, as well as drastic teaching reform, they often only stay in class forms and achievement projects, unable to touch the nature of teaching. Teachers' teaching ideas are still very old with an emphasis on induction and summary of theoretical knowledge, and they make students passively accept the teaching content in a way of infusion, while extremely neglect the individual situation of students, and selectively neglect students' learning ability, learning attitude and learning interest, which is bad for students' mastery of knowledge and the development of their ability and quality. The author found that in the traditional classroom of English linguistics, the course content is lengthy and boring, and nearly one third of the students in the classroom sleep or chat. This kind of teaching environment will only have an opposite effect on students' development. 


\section{Lack of teaching interaction}

The interaction in the class can enhance the overall effects of teaching, so as to promote students' enthusiasm in English linguistics learning and make students acquire knowledge voluntarily both in and outside the classroom, thus making students get the development of thinking. This is the new teaching idea and one of the important methods of quality education. The interactive design of classroom teaching plays an important role in the lively classroom atmosphere. However, in the current English linguistics teaching classroom, the classroom teaching effects are without animation, the teaching content is boring, there is almost no interaction between teachers and students, and students even have few opportunities to ask questions for a certain knowledge point they don't understand in the classroom, classroom openness is not high with very poor interaction.

\section{The Orientation of English linguistics Curriculum Reform}

\section{The teaching content should achieve the teaching objectives}

English linguistics courses have their own intrinsic value and meaning, so students can improve their inner knowledge through learning, and gradually improve their language learning ability. In order to achieve the teaching purpose of English linguistics, it is necessary for teachers to clearly recognize that students should focus on practicality and independence in the learning process. The development of teaching content should be based on the practicality and independence instead of blindly copying the theoretical knowledge. For example, in the teaching of social linguistics, the network resources can be used as a supplement to enable students to better grasp the practical skills of social practice, so as to improve their comprehensive proficiency ${ }^{[2]}$.

\section{Pay attention to students' subject status in teaching activities}

Teachers and students play different roles in teaching activities, in which students are the subject while teachers are the leading role. Therefore, in the curriculum reform, it is necessary to attach great importance to students' subject status and give full play to the teachers' leading role, so as to cultivate students' interest in learning and independent learning ability, and it is also necessary to develop different teaching methods, combining with different characteristics of different students, to improve students' linguistics knowledge proficiency.

\section{Carefully carry out teaching design}

The teaching content design is also an important part in the curriculum reform. In order to avoid the boring teaching activities in class in the past, teachers need to meticulously make pre-class preparation and design classroom teaching activities. On one hand, teachers should increase teaching interaction, and have communication with students through the interaction in the teaching content, and timely find students' problems in learning; on the other hand, teachers should make the teaching content more targeted, and can adapt in the teaching, and solve the students' learning difficulties and confusion appearing in their learning in a timely manner. For example, in the teaching of English expression ability, in order to improve students' English expression, the application of tourism, daily communication and other scenes can be designed to create an environment for students to communicate in English, so as to improve their ability to express English.

\section{The Practical Application of Task-based Teaching in English Linguistics Teaching}

For the orientation of English linguistics reform, in this thesis the task-based teaching method is applied to English teaching activities. The tasks not only ensure the teaching content is value-oriented and targeted, but also improve the students' knowledge and ability.

\section{The teacher's task-based teaching preparation}

Task-based teaching is to stimulate and give full play to the inherent potential of students through the completion of the task. The wonderful task design allows students to improve their learning ability through practice, perception, participation and cooperation. This method coincides with the teaching reform of English linguistics. The key to task-based teaching is the design of the 
task content, which requires teachers to master the essence of task-based teaching, so as to design tasks which can help students to improve their learning ability. In the design process, teachers can design tasks from the following aspects. First of all, for the students' learning methods, the task content can focus on the collection and reorganization of learning resources and the argument and expression of learning conclusions, so that students can master the good learning methods in the completion of the tasks at the same time; Secondly, for students' self-confidence enhancement, linguistic goals can be made step by step so that students can have sense of accomplishment when completing the tasks. Thirdly, the sense of responsibility is also very important for students in the learning process. Scenes with sense of substitution can be created to make students suffer difficulties and setbacks in the process of completing the tasks to develop their unswerving characters ${ }^{[3]}$

\section{The pre-task practice}

British scholar Williams published a monograph An Introduction to Task-based Learning in 1996, in which the author elaborated on the phases and methods of task-based teaching. It constructively divided the teaching process into three phases: pre-task, task cycle and post-task, so as to make the task-based teaching with authenticity, level and operability. Combined with Williams' three-phase theory and English linguistics teaching reform objectives, the task-based teaching can be designed. The pre-task phase refers to that the teacher carry out teaching activities after designing teaching tasks for the teaching content of one class. For example, in the design of pragmatic teaching tasks, the purpose is to enable students to better grasp the language meaning's changing, multi-faceted and other characteristics in the application of specific context. In this regard, teachers can join the news, advertising, daily-life or humor language in the tasks, and propose students to do a search task of language environment. The task can be the various meanings and characteristics of some word or phrase in the application in the created language environment, so as to inspire students to think about the reasons why these words are not changed in the context. Such tasks cannot only arouse students' interest and desire to learn through independent thinking, but also develop students' ability to explore and solve problems. The study of English linguistics can lay the foundation for theoretical study.

\section{The task cycle phase practice}

During the task cycle phase, teaching methods are mainly reflected in the role of teachers and students in the teaching environment. In the classroom of pragmatics, the teacher is mainly responsible for playing the role of mentor, encourager and organizer, and the students are responsible for playing a role to complete the task. The students are guided by the teachers in a happy and pleasant atmosphere that they find problems, put forward ideas, discuss ideas and solve the problems, so that students become the subject of classroom teaching and more quickly accept the knowledge to enhance themselves. In teaching practice, question-and-answer method can be used to achieve open teaching. First of all, the teacher pre-arranged the learning content, and whenever students encountered problems which cannot be solved alone in the process of preview, they can brainstorm together with other students to solve the problem. When most of the students are unable to solve the problem, teachers need to help students understand the problem and guide students to solve the problem, so that students and teachers can participate in the process of solving problems, and categorize the problem as a difficult point, and thus find the problems that students are prone to have in the learning process. Task-based English linguistics teaching can avoid the shortcomings of passive learning and infusion teaching in the past from the aspects of methods and processes. The learning focus is more prominent, students have more curiosity and learning motivation, and the learning effects are better through completing tasks and solving problems together.

\section{The post-task phase}

Linguistic learning is often thought to be boring, and many students consider linguistic knowledge is isolated, useless and abstract in their study summary ${ }^{[4]}$. However, in fact, linguistics is closely linked with life with high practical value. Linguistics not only enables students to master the theoretical knowledge, but also to a certain extent, grasps and verifies language phenomena, so 
as to better solve language problems. Therefore, after the task-based teaching, students should have a more comprehensive understanding of the value and meaning of the knowledge points and linguistics learned in the classroom through consolidation and repetitive exercises. For example, students' focus on self-learning process can develop their self-monitoring and learning evaluation ability, so as to promote their future learning. As for the evaluation of teaching activities and learning methods, it is necessary to avoid the single or test-based traditional evaluation methods and adopt the method of combining the process evaluation and the final evaluation so that the evaluation is more comprehensive, scientific and objective. The study of the second foreign language is difficult, based on the theory of constructivism, the task-based teaching mode is a new type of language teaching method, which make the learners become the witnesses of the language structure, through the methods of "completion", "experience" and "innovation", so as to make the teaching content have more practical significance.

\section{Reflection on teaching activities}

The task-based teaching mode, originated in the 1980s, is the extension of the communicative teaching thought in the twentieth century, but also the education industry's reflection and practical achievements on teaching methods when the traditional teaching-contact-expression teaching mode -“3Ps” - cannot obtain satisfactory teaching results. With the development, task-based teaching has not only been limited to the surface level, change of teaching methods, but also deepen the pursuit of the meaning and value of learning, so as to form profound and rational learning methods. For example, Ellis and Nunan, famous educational scholars at the beginning of the 21st century, put forward the important value of task-based teaching theory and practice. Therefore, the reflection and reorganization of task-based teaching activities will focus on students' completion of the tasks to determine whether students fully grasp the important knowledge points of the classroom teaching, and whether students have independent problem-solving ability and problem-exploring ability. An excellent task-based teaching design not only enables students to master the theoretical knowledge through tasks, but also cultivate students' learning ability. When the task-based teaching did not achieve the two requirements, teachers need to reflect on the process of task-based teaching activities, and examine and weigh what problems the task design have from the task design, the highlighted key knowledge in the task, task completion and students' evaluation on the difficulty of the task content, and determine to improve. The task-based teaching can serve for the teaching objectives through the improved task design, for example, the design of language culture, language sensitivity and enthusiasm of students to learn in the task-based teaching can embody the teaching value.

\section{Conclusion}

In summary, due to the characteristics of English linguistics courses, whether the design of teaching methods can enable students to improve their ability or not is essential and plays a decisive role. Task-based teaching has experienced decades of development, which has an important impact both in linguistics and education, and has practical value and significance. In this thesis, combined with the teaching content of the practical language courses, according to the requirements of the task-based teaching mode, specific teaching methods are formed. The increased participation of students and teachers in the task improves students' comprehensive knowledge and ability.

\section{References}

[1] Mou Changqing, Zhang Ling: The Linguistics Curriculum Reform Based on the Task-based Teaching mode [J]. Literature Education (Volume one), 2016, (04): 161.

[2] Kang Yinghua: Study on the Reform of English Linguistics Teaching mode in Colleges and Universities [J]. Journal of Chifeng University (Natural Science Edition), 2015, 31 (19): 218-219

[3] Chen Yan: Discussion on the Reform of English Linguistics Teaching mode in Colleges and Universities [J]. Journal of Mudanjiang University, 2012, 21 (10): 164-166. 
[4] Dang Tingyun: The Study on Linguistics Curriculum Teaching Based on the Task-based Teaching mode [J]. English Square (Academic Study), 2012, (08): 121-122. 